\title{
Influences of Annealing Temperature on the Optical and Structural Properties of Manganese Oxide Thin Film by Zn Doping from Sol-Gel Technique
}

\author{
S. Pishdadian* And A.M. Shariati Ghaleno \\ Department of Physics, Shahrood Branch, Islamic Azad University, Shahrood, Iran
}

(Received February 26, 2012)

\begin{abstract}
Thin films of $\mathrm{MnO}_{2}, \mathrm{Mn}_{2} \mathrm{O}_{3}$, and $\mathrm{Mn}_{3} \mathrm{O}_{4}$ have been grown from single precursor solution by varying the post-annealing condition on the glass and corning substrate using a sol-gel technique. By annealing in air and at temperature between 600 and $800{ }^{\circ} \mathrm{C}$, cubic $\mathrm{Mn}_{2} \mathrm{O}_{3}$ films could be formed. The films were thermally annealed at different temperatures between 300 and $800^{\circ} \mathrm{C}$ to create different crystalline structure. Even under the air-annealing condition, $\mathrm{Zn}$ doping results in a structural transformation from cubic $\mathrm{Zn}_{x} \mathrm{Mn}_{2-x} \mathrm{O}_{3}$ to tetragonal $\mathrm{Zn}_{x} \mathrm{Mn}_{3-x} \mathrm{O}_{4}$. X-ray diffraction, atomic force microscopy, and UV-visible spectra were used to characterize the effect of thermal annealing on the optical and structural properties of a $\mathrm{Zn}$ doped manganese oxide thin film. Optical properties of the $\mathrm{Mn}_{2} \mathrm{O}_{3}$ and $\mathrm{Mn}_{3} \mathrm{O}_{4}$ films have been investigated by pointwise unconditioned minimization approach.
\end{abstract}

DOI: $10.12693 /$ APhysPolA.123.741

PACS: 78.66.-w, 81.10.-h, 68.55.Jk

\section{Introduction}

Manganese oxide is a transition metal oxide. $\mathrm{Cu}$ bic $\mathrm{Mn}_{2} \mathrm{O}_{3}$, tetragonal $\mathrm{Mn}_{3} \mathrm{O}_{4}$ and cubic $\mathrm{MnO}$ structures could be obtained from $\mathrm{MnO}_{2}$ by varying the post-annealing conditions. Among these oxides, $\mathrm{MnO}_{2}$ is most stable. Such varieties in their structures and hence in physical and chemical properties make them attractive to study their fundamental physical properties and technological applications. Thin films of manganese-based oxide can be potentially used as rechargeable batteries, catalysts, electrochemical capacitors, sensors and magnetoelectronic devices. Various structural, electronic, and magnetic properties of manganese-based oxides are mainly affected by various oxidation conditions and locations of the manganese ions in the unit cell of these oxides. Different methods have been employed to fabricate manganese oxide thin films, such as sputtering $[1,2]$, electron beam evaporation [3], pulse laser deposition $[4,5]$, molecular beam epitaxy [6, 7], electrochemical [8], spray pyrolysis $[9,10]$ and sol-gel $[11,12]$. Although the structural, electronic and magnetic properties of manganese oxide have been well investigated, to the author's knowledge, their optical properties have hardly been investigated so far. In this work, various manganese oxide films have been prepared by sol-gel, employing dip-coating method. $\mathrm{Mn}_{2} \mathrm{O}_{3}$ and $\mathrm{Mn}_{3} \mathrm{O}_{4}$ structures could be obtained by changing the annealing condition. Also, a structural transformation from $\mathrm{Mn}_{2} \mathrm{O}_{3}$ to $\mathrm{Mn}_{3} \mathrm{O}_{4}$ was observed by $\mathrm{Zn}$ doping. The effects of annealing on the structural and optical constants were investigated.

* corresponding author; e-mail: spishdadian@iau-shahrood.ac.ir

\section{Experimental}

$\mathrm{MnO}_{2}, \quad \mathrm{Mn}_{2} \mathrm{O}_{3}$ and $\mathrm{Mn}_{3} \mathrm{O}_{4}$ films were deposited on soda lime and corning substrate by sol-gel employing dip-coating method. The sol was prepared by dissolving $\mathrm{Mn}\left(\mathrm{CH}_{3} \mathrm{COO}\right)_{2} \cdot 4 \mathrm{H}_{2} \mathrm{O}$ as precursor and monoethanolamin (MEA) as complexing agents and 2-methoxyethanol as solvent. The mixture was stirred at $80^{\circ} \mathrm{C}$ for $3 \mathrm{~h}$. For $\mathrm{Zn}$ doping, $\mathrm{Zn}\left(\mathrm{C}_{2} \mathrm{H}_{5}\right)_{2} \cdot 2 \mathrm{H}_{2} \mathrm{O}$ and $\mathrm{Mn}\left(\mathrm{CH}_{3} \mathrm{COO}\right)_{2} \cdot 4 \mathrm{H}_{2} \mathrm{O}$ powders were dissolved together. The coating solutions were aged for one day at room temperature, and then were dip-coated on the substrate. Resulted thin film was heated at $90^{\circ} \mathrm{C}$ for 5 min after each deposition. This process was repeated seven times to increase the film thickness. After drying, these films were annealed at $300-800^{\circ} \mathrm{C}$ in air for $4 \mathrm{~h}$. An X-ray diffractometer (B8-advance Bruker axs) was used to determine the crystallite structure of the films. Detailed morphological analysis of the manganese oxide thin films was carried out by atomic force microscopy (AFM) using a Dual Scope Microscope model DME 2401. Normal-incidence transmittance was measured over the wavelength range 300-1000 nm using a Himadzu Uv-1800 spectrophotometer. The idea of assuming a closed formula for $n$ and $k$ depending on few coefficients has been exploited in celebrated methods. The methods originated on this idea are efficient when the transmittance curve exhibits some fringe patterns, representing rather large zones of the spectrum where $k(\lambda)$ is almost null. The transmission of a thin absorbing film deposited on a thick transparent substrate is given by

$$
T=\frac{A x}{B-C x+D x^{2}} .
$$

Instead of imposing a functional form for $n(\lambda)$ and $k(\lambda)$, the phenomenological constraints that restrict the variability of these functions were stated explicitly so that 
the estimation problem is formed as follows:

Minimize $\sum \mid$ Theoretical $T(\lambda)$ - Measured $\left.T(\lambda)\right|^{2} \cdot(2)$

In this way, well behaved functions $n(\lambda)$ and $k(\lambda)$ can be obtained without severe restrictions that may damage the quality of the fitting [13]. In this paper, the optical constants and the thickness of thin films were estimated by recent method.

\section{Results and discussion}

The manganese oxide films showed amorphous phase with no observable X-ray diffraction (XRD) peak when the annealed temperature was less than $500^{\circ} \mathrm{C}$. As shown in Fig. 1, annealing the deposited films in air and also at $600-800{ }^{\circ} \mathrm{C}$ for $4 \mathrm{~h}$ led to good-quality formation of $\mathrm{Mn}_{2} \mathrm{O}_{3}$. The XRD data for the films exhibit characteristic peaks for $\mathrm{Mn}_{2} \mathrm{O}_{3}$ without any other phases. The estimated cubic lattice constant of the $\mathrm{Mn}_{2} \mathrm{O}_{3}$ film is $9.36 \AA$, which is quite close to $9.40 \AA$ that was reported for bulk $\mathrm{Mn}_{2} \mathrm{O}_{3}$ [14]. When $\mathrm{Zn}$ was added in the precursor solution, a structural transformation was observed from cubic $\mathrm{Mn}_{2} \mathrm{O}_{3}$ to tetragonal $\mathrm{Mn}_{3} \mathrm{O}_{4}$ even under the same air-annealing condition. Figure 2 shows that the XRD spectrum of $\mathrm{Zn}$-doped $\mathrm{Mn}_{2} \mathrm{O}_{3}$ film looks quite similar to that of pure $\mathrm{Mn}_{2} \mathrm{O}_{3}$. This film can be described as $\mathrm{Zn}_{x} \mathrm{Mn}_{2-x} \mathrm{O}_{3}$ with $x=0.06$.

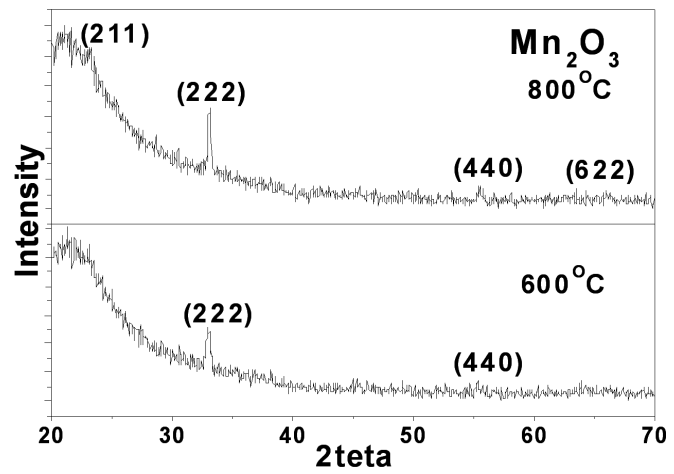

Fig. 1. XRD spectra of manganese oxide films obtained by air-annealing at $300-800^{\circ} \mathrm{C}$ for $4 \mathrm{~h}$.

The estimated cubic lattice constant of the $\mathrm{Mn}_{2} \mathrm{O}_{3}$ film from $\mathrm{Zn}_{x} \mathrm{Mn}_{2-x} \mathrm{O}_{3}$ with $x=0.06$ is $10.26 \AA$. However, it is shown that the $\mathrm{Zn}$-doped $\mathrm{Mn}_{2} \mathrm{O}_{3}$ film also contains minor $\mathrm{Mn}_{3} \mathrm{O}_{4}$-like phase as marked by ${ }^{*}$ in Fig. 2. By increasing the $\mathrm{Zn}$ content in the precursor solution as $\mathrm{Zn}_{x} \mathrm{Mn}_{3-x} \mathrm{O}_{4}$ with $x=0.16-0.36$ the resulted films exhibit complete $\mathrm{Mn}_{3} \mathrm{O}_{4}$ like phase at $600-800{ }^{\circ} \mathrm{C}$ as shown in Fig. 3. The films which were annealed at the temperature below the $600{ }^{\circ} \mathrm{C}$ were amorphous. The estimated tetragonal lattice constants of $\mathrm{Mn}_{3} \mathrm{O}_{4}$ film are $a=6.44 \AA$ and $c=10.24 \AA$, which are in agreement with previously reported values of 5.760 and $9.440 \AA$, respectively, in case of bulk $\mathrm{Mn}_{3} \mathrm{O}_{4}$ [15]. The effects of annealing temperature on the surface morphology of $\mathrm{Zn}_{x} \mathrm{Mn}_{3-x} \mathrm{O}_{4}(x=0.36)$ films are clearly evidenced in Fig. 4 . The surfaces of the

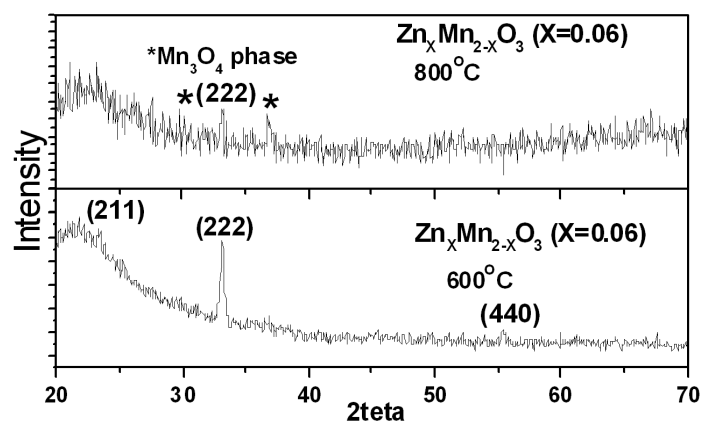

Fig. 2. XRD spectra of $\mathrm{Zn}_{x} \mathrm{Mn}_{2-x} \mathrm{O}_{3}(x=0.06)$ obtained by air-annealing at 600 and $800{ }^{\circ} \mathrm{C}$ for $4 \mathrm{~h}$.

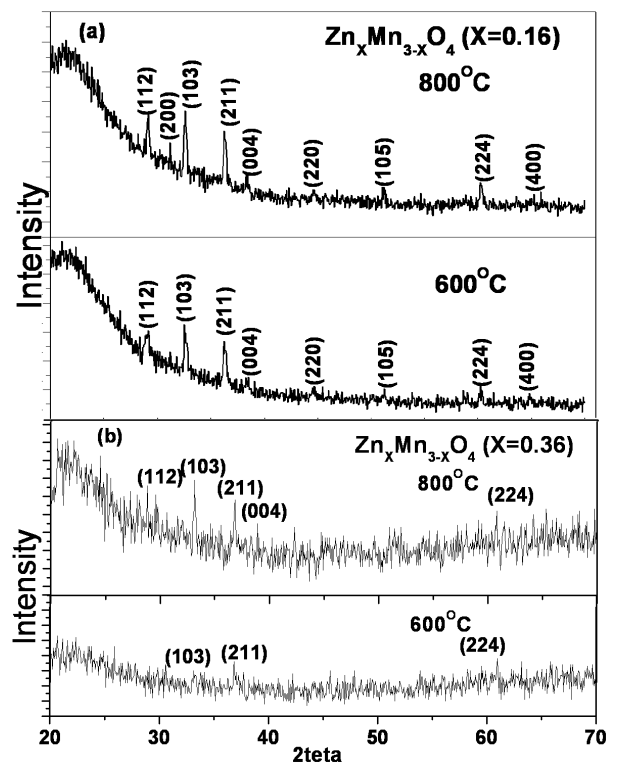

Fig. 3. XRD spectra of $\mathrm{Zn}_{x} \mathrm{Mn}_{3-x} \mathrm{O}_{4}$ : (a) $x=0.16$ and (b) $x=0.36$ obtained by air-annealing at 600 and $800^{\circ} \mathrm{C}$ for $4 \mathrm{~h}$.

films show crack free areas in the explored section. Manganese oxides which were annealed at $300^{\circ} \mathrm{C}$ and $400^{\circ} \mathrm{C}$ exhibit different appearance (see Fig. $4 \mathrm{a}$ and b). The film which was annealed at $400^{\circ} \mathrm{C}$ shows the smaller grains and hence has lower roughness and thickness than the film which was annealed at $300^{\circ} \mathrm{C}$. At $500^{\circ} \mathrm{C}$, the significant change in morphology could be caused by crystallization of the amorphous $\mathrm{MnO}_{2}$, since the corresponding formation of crystalline $\mathrm{Mn}_{3} \mathrm{O}_{4}$. As the annealing temperature is raised to $600^{\circ} \mathrm{C}$, the oxide morphology becomes islands (as shown in Fig. 6d). The morphology of the oxide which was annealed at temperatures higher than $600{ }^{\circ} \mathrm{C}$ is presented in Fig. 6e. Oxide corresponding to the phase transformation to $\mathrm{Mn}_{3} \mathrm{O}_{4}$ (from XRD) can be observed.

Figures 5-8 show the optical transmittance spectra of manganese oxide and $\mathrm{Zn}_{x} \mathrm{Mn}_{2-x} \mathrm{O}_{3}$ with $x=0.06$ and $\mathrm{Zn}_{x} \mathrm{Mn}_{3-x} \mathrm{O}_{4}(x=0.16-0.36)$ films which were annealed 


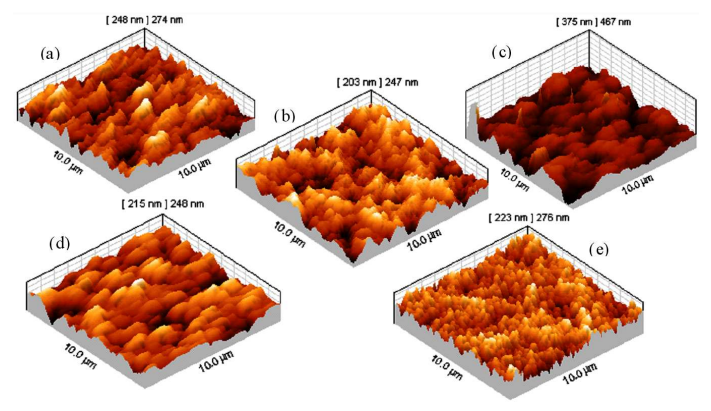

Fig. 4. AFM images of $\mathrm{Zn}_{x} \mathrm{Mn}_{3-x} \mathrm{O}_{4} \quad(x=0.36)$ films in (a) $300{ }^{\circ} \mathrm{C}$, (b) $400{ }^{\circ} \mathrm{C}$, (c) $500{ }^{\circ} \mathrm{C}$, (d) $600{ }^{\circ} \mathrm{C}$, (e) $800{ }^{\circ} \mathrm{C}$.

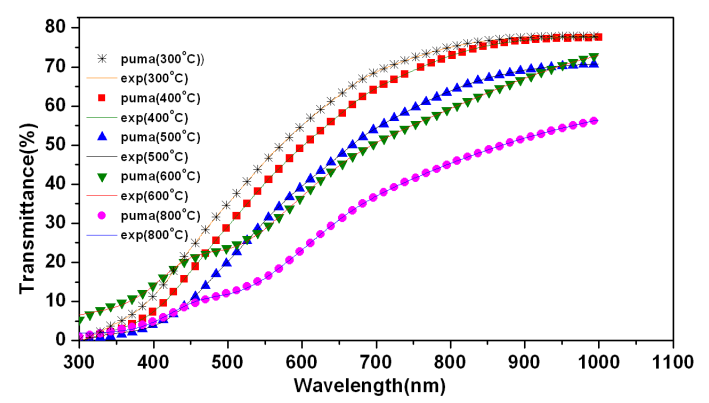

Fig. 5. Transmittance spectra of thin manganese oxide film by changes of annealing temperature.

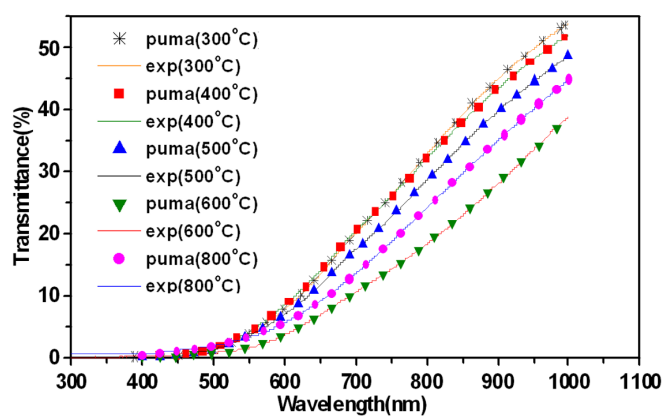

Fig. 6. Transmittance spectra of thin $\mathrm{Zn}_{x} \mathrm{Mn}_{2-x} \mathrm{O}_{3}$ $(x=0.06)$ film by changes of annealing temperature.

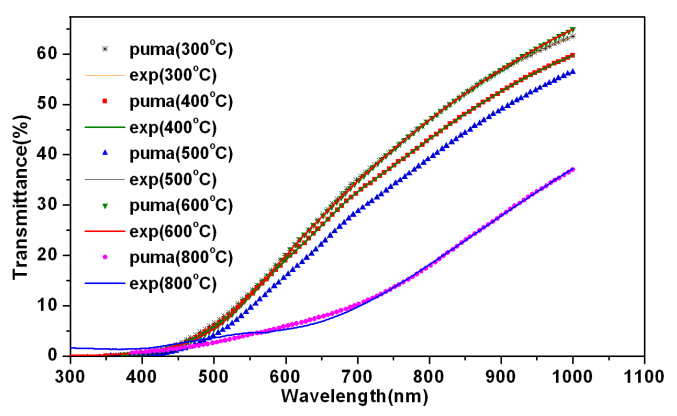

Fig. 7. Transmittance spectra of thin $\mathrm{Zn}_{x} \mathrm{Mn}_{3-x} \mathrm{O}_{4}$ $(x=0.16)$ film by changes of annealing temperature.

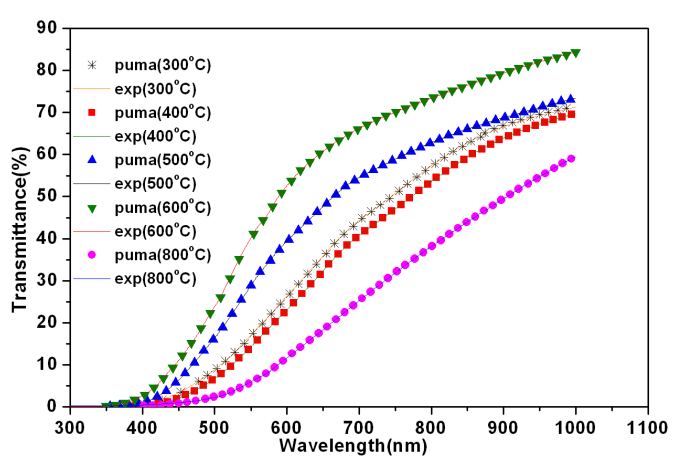

Fig. 8. Transmittance spectra of thin $\mathrm{Zn}_{x} \mathrm{Mn}_{3-x} \mathrm{O}_{4}$ $(x=0.36)$ film by changes of annealing temperature.

at different temperatures from $300{ }^{\circ} \mathrm{C}$ to $800^{\circ} \mathrm{C}$. The transmittance of the films was decreased when the annealing temperature increased from $300{ }^{\circ} \mathrm{C}$ to $800{ }^{\circ} \mathrm{C}$. In Fig. 5 the transmittance for the films which were annealed at $300-500^{\circ} \mathrm{C}$ has significant differences compared to the others because of the $\mathrm{MnO}_{2}$ phase transformation to $\mathrm{Mn}_{2} \mathrm{O}_{3}$ (from XRD can also be observed). When $\mathrm{Zn}$ was added in the precursor solution as $\mathrm{Zn}_{x} \mathrm{Mn}_{2-x} \mathrm{O}_{3}$ $(x=0.06)$ the transmittance of films exhibit complete $\mathrm{Mn}_{2} \mathrm{O}_{3}$ like phase at $600-800^{\circ} \mathrm{C}$ (from XRD) (Fig. 6). By increasing the $\mathrm{Zn}$ content as $\mathrm{Zn}_{x} \mathrm{Mn}_{3-x} \mathrm{O}_{4}$ the transmittance of films exhibit complete $\mathrm{Mn}_{3} \mathrm{O}_{4}$ like phase at 500-800 ${ }^{\circ} \mathrm{C}$ (from XRD) (Figs. 7, 8). The transmittance of the manganese oxide thin films shows decreases in the visible region as a result of increasing annealing temperature. By increasing the $\mathrm{Zn}$, the transmittance of films which were annealed at $500-800^{\circ} \mathrm{C}$ has considerable differences in comparison with the undoped films; because a structural transformation was observed from $\mathrm{MnO}_{2}$ to $\mathrm{Mn}_{2} \mathrm{O}_{3}$ and $\mathrm{Mn}_{3} \mathrm{O}_{4}$. Optical properties of manganese oxide thin films were determined by transmittance spectra and with optimization of data. When the annealed temperature increased from $300^{\circ} \mathrm{C}$ to $800^{\circ} \mathrm{C}$, the thickness of manganese oxide thin films was decreased from $227 \mathrm{~nm}$ to $150 \mathrm{~nm}$ and it was also reduced from 207 to $154 \mathrm{~nm}$ in case of $\mathrm{Zn}$ doped sample $(x=0.36)$. The annealing temperature is found to have a significant influence on the optical properties of the films. The refractive index of a thin film is proportional to the density of the film.

The dispersion of refractive index of the films for different annealing temperature is represented in Figs. 9, 10. The high change of refractive index in the entire wavelength range is a potential in using of this material in reflective coating applications. The refractive index in all films increases when the annealing temperature increased from $300{ }^{\circ} \mathrm{C}$ to $800^{\circ} \mathrm{C}$. The refractive index for the films annealed at $600-800^{\circ} \mathrm{C}$ has significant differences compared to the others because of the $\mathrm{MnO}_{2}$ phase transformation to $\mathrm{Mn}_{2} \mathrm{O}_{3}$. By increasing the $\mathrm{Zn}$, the refractive index for the films which were annealed at $500-800{ }^{\circ} \mathrm{C}$ has remarkable differences compared to the undoped films; because a structural transformation was observed from $\mathrm{MnO}_{2}$ and $\mathrm{Mn}_{2} \mathrm{O}_{3}$ to $\mathrm{Mn}_{3} \mathrm{O}_{4}$. 


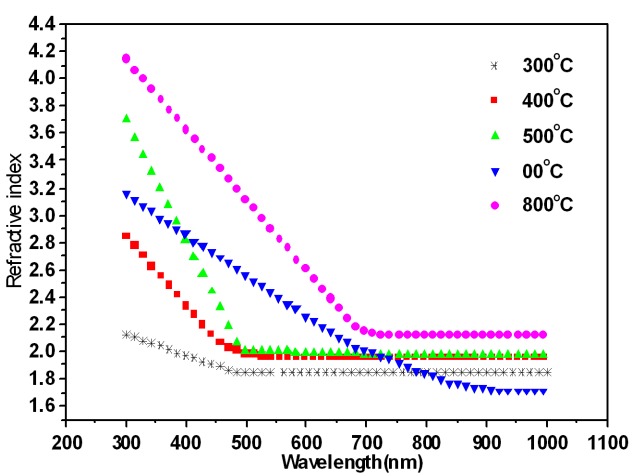

Fig. 9. Dispersion of refractive index of thin manganese oxide film by changes of annealing temperature.

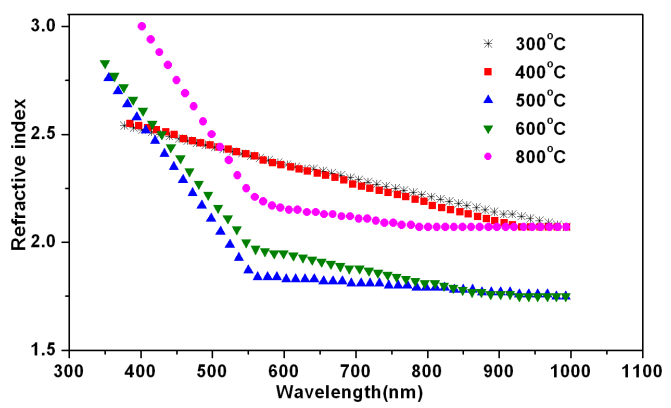

Fig. 10. Dispersion of refractive index of thin $\mathrm{Zn}_{x} \mathrm{Mn}_{3-x} \mathrm{O}_{4}(x=0.36)$ film by changes of annealing temperature.

The spectral behaviour of extinction coefficient as a function of annealing temperature is shown in Figs. 11, 12. As shown in the figure, the extinction coefficient increases when the annealing temperature increases from 300 to $800{ }^{\circ} \mathrm{C}$. The extinction coefficient for the films which were annealed at $600-800^{\circ} \mathrm{C}$ is highly different from the other ones as a result of the $\mathrm{MnO}_{2}$ phase transformation to $\mathrm{Mn}_{2} \mathrm{O}_{3}$. By increasing the $\mathrm{Zn}$, the refractive index of the films which were annealed at

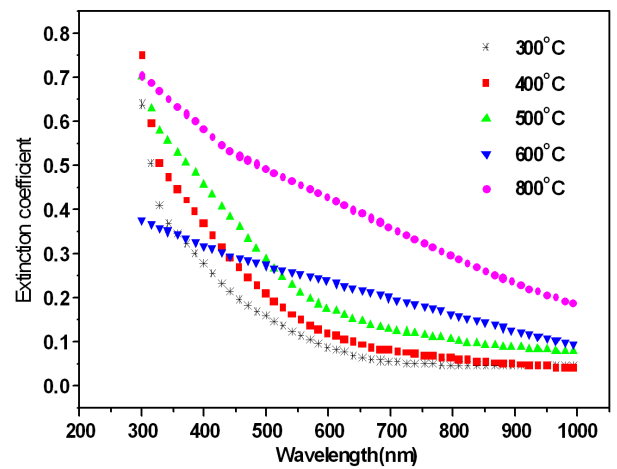

Fig. 11. Wavelength dependence of extinction coefficient for thin manganese oxide film by changes of annealing temperature.

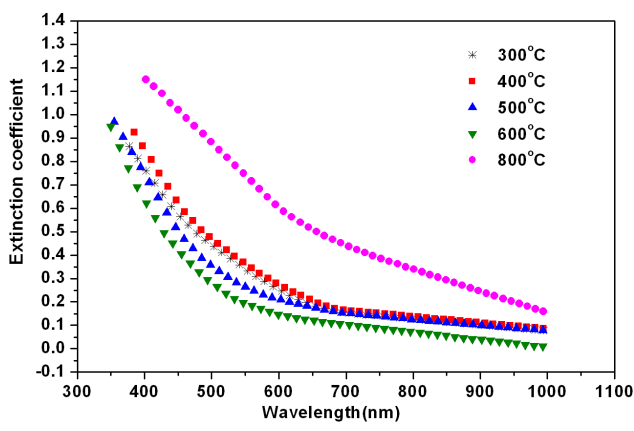

Fig. 12. Wavelength dependence of extinction coefficient for thin $\mathrm{Zn}_{x} \mathrm{Mn}_{3-x} \mathrm{O}_{4}(x=0.36)$ film by changes of annealing temperature.

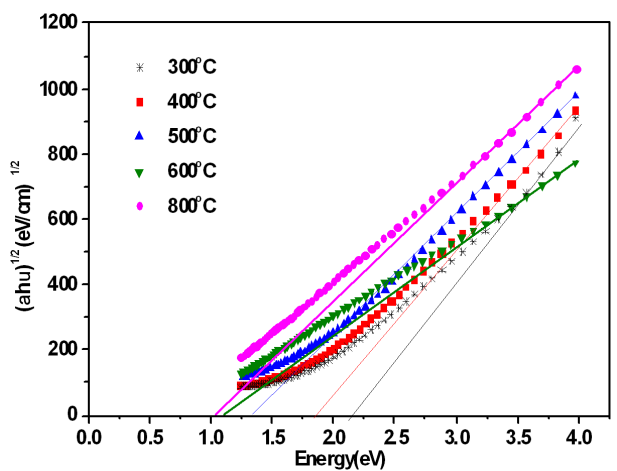

Fig. 13. Variation of $(\alpha h \nu)^{1 / 2}$ with photon energy for manganese oxide thin films with change of annealing temperature.

$500-800{ }^{\circ} \mathrm{C}$ important differences are found compared to the undoped films; because a structural transformation was observed from $\mathrm{MnO}_{2}$ and $\mathrm{Mn}_{2} \mathrm{O}_{3}$ to $\mathrm{Mn}_{3} \mathrm{O}_{4}$. The absorption coefficient was calculated from the extinction coefficient

$$
\alpha=\frac{4 \pi k}{\lambda} \text {. }
$$

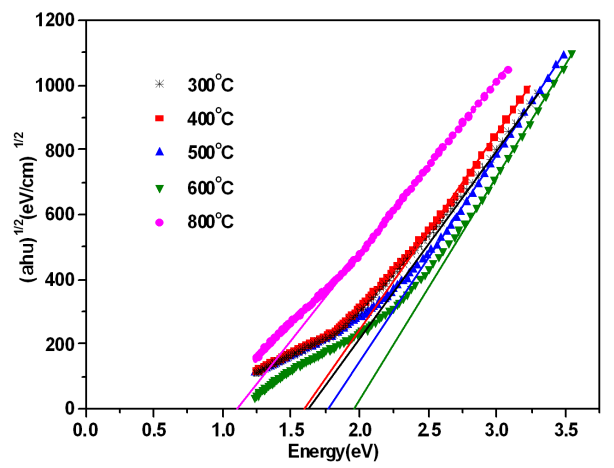

Fig. 14. Variation of $(\alpha h \nu)^{1 / 2}$ with photon energy for thin $\mathrm{Zn}_{x} \mathrm{Mn}_{3-x} \mathrm{O}_{4}(x=0.36)$ film by changes of annealing temperature. 


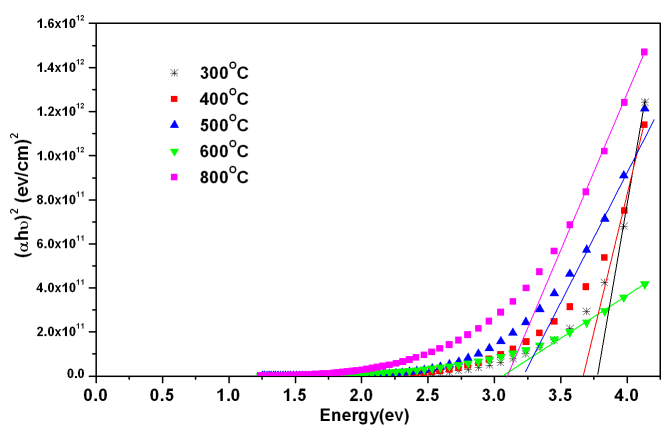

Fig. 15. Variation of $(\alpha h \nu)^{2}$ with photon energy for manganese oxide thin films with change of annealing temperature.

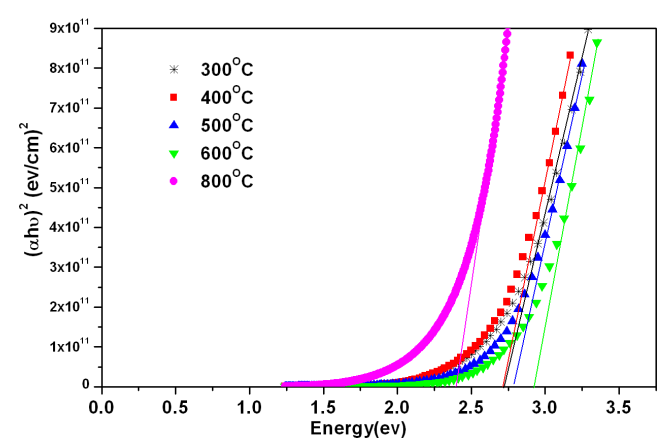

Fig. 16. Variation of $(\alpha h \nu)^{2}$ with photon energy for thin $\mathrm{Zn}_{x} \mathrm{Mn}_{3-x} \mathrm{O}_{4}(x=0.36)$ film by changes of annealing temperature.

Then $(\alpha h \nu)^{\eta}$ was plotted as a function of $h \nu$, where $h \nu$ is the photon energy, and $\eta$ is a constant that depends on the types of transitions. The values of $1 / 2$ and 2 for $\eta$ represent the indirect and direct transitions, respectively. No value for the direct energy gap of $\mathrm{MnO}_{2}$ and indirect $\mathrm{Mn}_{3} \mathrm{O}_{4}$ have been reported. In this plot, the horizontal intercept represents the energy gap.

The plot of $(\alpha h \nu)^{1 / 2}$ and $(\alpha h \nu)^{2}$ with respect to $h \nu$ for indirect and direct optical transition of thin films is represented in Figs. 13-16. The direct and indirect band gaps of the films were decreased when the annealing temperature increased from $300^{\circ} \mathrm{C}$ to $800^{\circ} \mathrm{C}$. The direct and indirect energy gaps for the films which were annealed at $600-800^{\circ} \mathrm{C}$ show meaningful differences compared to the other due to the $\mathrm{MnO}_{2}$ phase transformation to $\mathrm{Mn}_{2} \mathrm{O}_{3}$. By increasing the $\mathrm{Zn}$, the direct and indirect energy gaps of the films which were annealed at $500-800^{\circ} \mathrm{C}$ present significant changes in comparison with the undoped films; a structural transformation which was observed from $\mathrm{MnO}_{2}$ and $\mathrm{Mn}_{2} \mathrm{O}_{3}$ to $\mathrm{Mn}_{3} \mathrm{O}_{4}$ can be led to it.

\section{Conclusions}

In this work, thin films of $\mathrm{MnO}_{2}, \mathrm{Mn}_{2} \mathrm{O}_{3}$ and $\mathrm{Mn}_{3} \mathrm{O}_{4}$ were deposited by sol-gel using dip-coating technique and were annealed at $300^{\circ} \mathrm{C}$ to $800^{\circ} \mathrm{C}$. We studied variations in the optical and structural properties of these thin films that resulted from changing the temperature of annealing. The annealing temperature expressively influences on optical and structural properties of the films. The optical band gap of the films decreases as a result of increasing the annealing temperature. $\mathrm{Zn}$ additive induces a structural transformation from $\mathrm{Mn}_{2} \mathrm{O}_{3}$ to $\mathrm{Mn}_{3} \mathrm{O}_{4}$ even under the same air-annealing condition. Optical properties of $\mathrm{Mn}_{2} \mathrm{O}_{3}, \mathrm{Mn}_{3} \mathrm{O}_{4}, \mathrm{Zn}_{x} \mathrm{Mn}_{2-x} \mathrm{O}_{3}(x=0.06)$ and $\mathrm{Zn}_{x} \mathrm{Mn}_{3-x} \mathrm{O}_{4} \quad(x=0.16-0.36)$ were calculated by using the pointwise unconditioned minimization approach (PUMA) numerical approximation method from the experimental spectral transmittance. The calculated energy band gaps from optical data in this study are in good agreement with the value of other works $[9,16]$.

\section{References}

[1] P. Fau, J.P. Bonino, A. Rousset, Appl. Sci. 78, 203 (1994).

[2] R.M. Vaalletta, W.A. Pliskin, J. Electrochem. Soc. 114, 944 (1967).

[3] T. Seike, J. Nagai, Sol. Energy Mater. 22, 107 (1991).

[4] H. Yang, H. al-Brithen, A.R. Smith, J.A. Borchers, R.L. Cappelletti, M.D. Vaudin, Appl. Phys. Lett. 78, 3860 (2001).

[5] O. Nilsen, H. Fjellvåg, A. Kjekshus, Thin Solid Films 444, 44 (2003).

[6] S.A. Chambers, Y. Liang, Surf. Sci. 123, 420 (1999).

[7] L.W. Guo. H. Makino, H.J. Ko, Y.F. Chen, T. Hanada, D.L. Peng, K. Inaba, T. Yao, J. Cryst. Growth 955, 227 (2001).

[8] M. Chigane, M. Ishikawa, J. Electrochem. Soc. 148, D96 (2001).

[9] A.K.M. Farid Ul Islam, R. Islam, K.A. Khan, Renew. En. 30, 2289 (2005).

[10] R.M. Valletta, J. Makris, W.A. Pliskin, Proc. Electron. Compon. Conf. 16, 31 (1966).

[11] K. Wang Joo Kim, Young. Ran Park, J. Crystal Growth 270, 162 (2004).

[12] Y.J. Park, J.G. Kim, H.T. Chung, H.G. Kim, Solid State Ionics 130, 203 (2000).

[13] I. Chambouleyron, J.M. Martinez, A.C. Moretti, Appl. Opt. 36, 1 (1997).

[14] JCPDS, International Centre for Diffraction Data 41, 1442 (1997).

[15] C.O. Paiva-Santos, R.F.C. Marques, M. Jafelicci, L.C. Varandaa, Powder Diffraction 17, 149 (2002).

[16] M.F. Al-Kuhaili, J. Vac. Sci. Technol. 24, 1746 (2006). 